\title{
GENETICS OF PSORIASIS AND PSORIATIC ARTHRITIS
}

\author{
A. MAThieU, A. CAUli, A. VACCA, A. MAMeli, G. PASSiU, G. PORRU, M. PIGA, \\ V. IBBA, V. MURA, S. SANNA \\ Chair of Rheumatology, University of Cagliari, Italy
}

\begin{abstract}
SUMMARY
Psoriasis and psoriatic arthritis are linked diseases characterised by (distinct ?) immune-mediated pathogenetic mechanisms and by a genetic background interacting with environmental factors. Some candidate susceptibility genes have been studied extensively; they include HLA genes, genes within the HLA region and genes outside the HLA region; among them corneodesmosin and other genes of PSORS1 region, MICA and TNF-a polymorphisms. The main findings in the literature are discussed.
\end{abstract}

Key words: Genetics, psosriasis, psoriatic arthritis

This review mainly summarises the genetic factors involved in conferring susceptibility to psoriatic arthritis (PsA); nevertheless it is important to underline some aspects concerning genetics of cutaneous psoriasis (Ps) because they often overlap with those of the articular manifestations in patients with PsA.

Immunogenetic studies both in Ps and in PsA have investigated the HLA genes, genes within the HLA region and genes outside the HLA region. It is noteworthy that HLA molecules function is to present peptide antigens to $\mathrm{T}$ lymphocytes and that this function may explain their association with disease; the differences in their structure are critical in determining the selective capability of presenting specific peptides (arthritogenic?). Nevertheless it is important to consider that the role of HLA alleles may be indirect, and that their association may be simply due to linkage disequilibrium with the gene/s directly involved in the disease susceptibility which are likely to be included in the same extended aplotype. Studies focusing on HLA related genes and genes encoded outside the HLA region have been performed since the specific biologic properties of the molecules encoded by these genes may well explain a possible role in the pathogenesis of chronic inflammatory arthropathy and

\section{Corresponding author:}

Alessandro Mathieu, MD

Università di Cagliari

Struttura Complessa di Reumatologia

ss 554, Monserrato

09042 Cagliari, Italy provide a rationale for the extensive studies on genetic polymorphisms.

In Ps it has been demonstrated a very strong association with the HLA allele Cw6, but only for the type I form (characterised by familial aggregation, moderate/severe skin involvement and clinical onset before the age of 40 years), while no association has been shown for type II (not familial, onset around 55/60 years). Others HLA alleles such as B13, Bw57 and DR7 have been associated with type I Ps but these findings may be due to their linkage disequilibrium with Cw6 (1, 2). $\mathrm{Cw}^{*} 0602$ has been shown to be the subtype with the strongest association with early onset, disease severity and higher frequency of guttate form $(3,4)$.

HLA-Cw6 gene is located on chromosome 6 in a region called PSORS1 which contains some genes possibly implicated in the susceptibility of Ps. Among them the CDSN gene, which encodes corneodesmosin, is one of the major candidate (5-8). The possible role of HLA-Cw6 in conferring susceptibility to Ps may be explained with its physiological role of presenting peptide antigens to the immune system, while in the case of CDSN a structural alteration of the corneodesmosin protein could be related with a possible role in initiating the pathologic process (8).

Although clear differences have been found among the populations studied, both HLA class I and II alleles have been associated with PsA. Among the first ones, HLA-B13, B17/Cw6, B16 with his splits B38 and B39 (the last one is also associated 
with disease progression) and B27 are included; among class II alleles, DR7 and DR4 are implicated (9-17). The presence of two susceptibility alleles, have been shown to confer an additional risk; this has been demonstrated for $\mathrm{Cw} 1$ and $\mathrm{B} 17$ when associated with B27 in the spondylitic subset (15). It has to be point out that the associations of the single HLA alleles are often restricted to specific clinical PsA subsets rather than PsA as a whole. Furthermore some associations, or the statistical significance of them, which have been found in some populations were not confirmed in studies performed on different ethnic groups. On this regard we focus on the association of B13, B17/Cw6 and DR7 with the oligoarticular asymmetric subset $(11,13-15)$, as well as B16 and his splits B38 and B39. Similarly, DR4 has been associated with the peripheral symmetric polyarticular subset $(9$, $10,12,13,17)$ while B27 has been classically linked with the axial sacroiliitis involvement (15, 18), expecially in bilateral sacroiliitis (19), with the exception of the population in Israel where this association has not been observed (20).

Among the genes encoded within the HLA region the polymorphic gene MICA (MHC class I chain related gene A), located close to B locus and TNF$\alpha$ and encoding for a stress inducible membrane glycoprotein, has been extensively studied. MICA molecule, found on intestinal epitelial cells and in inflammed synovium, is ligand for NKG2D expressed on NK on CD8+ T lymphocytes and on $\gamma \delta$ $\mathrm{T}$ cells, with no evidence that it is involved in antigen presentation $(21,22)$. Studies performed on caucasian population (23-25) have demonstrated that MICA-A9 confers susceptibility to PsA independently from $\mathrm{Cw}^{*} 0602$ and MICB, TNF- $\alpha$ and DRB1. As demonstrated for other alleles, MICAA9 preferentially associates with the polyarticular subset. This result has been confirmed by us and others in a multicenter Italian study which has showed also a "gene dosing" effect of MICA-A9 in conferring susceptibility to the polyarticular subset in overlap with axial involvement (Mameli et al. submitted).

Among other genes, TNF- $\alpha$ polymorphisms appear to be some of the most interesting because of their functional and pathogenetic role. In Ps, a positive association has been described for Ps vulgaris, but not pustolosis palmoplantaris, with -238 and -308 promoter polymorphysms (26). Considering PsA, the data so far available are conflicting (27-31). A recent study on three microsatellite and two TNF- $\alpha$ promoter polymorphisms showed a significant increase of TNFa6c1d3 aplotype in PsA patients compared with Ps alone, and a decrease in -308 compared to normal controls. It is noteworthy that TNFa6 microsatellite is associated with a decreased TNF- $\alpha$ production (27). Other studies did not report significant associations between TNF- $\alpha$ polymorphisms and PsA, while more recently, in a Canadian study, it has been described a significant association of -238A TNF- $\alpha$ polymorphism and PsA (31).

In conclusion, this short review focus on the complexity of the genetic susceptibility to Ps and PsA; the variety of the clinical features makes the understanding of the pathogenetic mechanisms even more difficult to achieve. On the other hand, the different susceptibility factors related with the different clinical subsets may, in turn, become the key to the understanding of the genetic mechanisms of disease susceptibility and of the role of the environmental factors involved.

\section{REFERENCES}

1. Henseler T, Christophers E. Psoriasis of early and late onset: characterization of two types of psoriasis vulgaris. J Am Acad Dermatol 1985; 13: 450-56.

2. Jenisch S, Westphal E, Nair RP Stuart P. Voorhees JJ. Christophers E et al. Linkage disequilibrium analysis of familial psoriasis: identification of multiple disease-associated MHC haplotypes. Tissue Antigens 1999; 53: 135-46.

3. Gudjonsson JE, Karason A, Antonsdottir AA, Runarsottir EH, Gulcher JR, Stefansson K et al. HLA-Cw6positive and HLA-Cw6-negative patients with psoriasis vulgaris have distinct clinical features. J Invest Dermatol 2002; 118: 362-5.

4. Mallon E, Bunce M, Savoie H, Rowe A, Newson R, Gatch F et al. HLA-C and guttate psoriasis. Br J Dermatol 2000; 143: 1177-82.

5. Tazi Ahnini R, Camp NJ, Cork MJ, Mee JB, Keohane SG, Duff GW et al. Novel genetic association between corneodesmosin (MHC S) gene and susceptibility to psoriasis. Hum Mol Genet 1999; 8: 1135-40.

6. Allen MH, Veal C, Faassen A Powis SH. Vaughan RW. Trembath RC et al. A non-HLA gene within the MHC in psoriasis. Lancet 1999; 353: 1589-90.

7. Jenish S, Kock S, Henselr T, Nair RP, Elder JT, Watts $\mathrm{CE}$ et al. Corneodesmosin gene polymorphism demonstrates strong linkage disequilibrium with HLA and association with psoriasis vulgaris. Tissue Antigens 1999; 54: 439-49.

8. Orrù S, Giuressi E, Casula M, Loizedda A, Murru R, Mulargia M, et al. Psoriasis is associated with a SNP haplotype of the corneodesmosin gene (CDSN). Tissue Antigens 2002; 6: 292-8.

9. Espinoza LR, Vasey FB, Gaylord SW, Dietz C, Bergen 
L, Bridgeford P, et al. Histocompatibility typing in the seronegative spondyloarthropaties: a survey. Semin Arthritis Rheum 1982; 11: 375-81.

10. Gerber LH, Murray CL, Perlman SG, Barth WF, Decker JL, Nigra TA ET al. Human lymphocyte antigens characterizing psoriatic arthritis and its subtypes. J Rheumatol 1982; 9: 703-7.

11. Armstrong RD, Panayi GS, Welsh KI. Histocompatibility antigens in psoriasis, psoriatic arthropathy, and ankylosing spondylitis. Ann Rheum Dis 1983; 42: 142-6.

12. Kantor SM, Hsu SH, Bias WB, Arnett FC. Clinical and immunological subsets of psoriatic arthritis. Clin Exp Rheumatol 1984; 2: 105-9.

13. Gladman DD, Urowitz MB, Anhorn KAB, Chalmers AM, H. Discordance between HLA-B27 and ankylosing spondiylitis: a family investigation. J Rheumatol 1986; 13: 129-36.

14. Sakkas LI, Loqueman N, Bird H, Vaughan RW, Welsh KI, Panayi GS. HLA class II and T cell receptor gene polymorphism in psoriatic arthritis and psoriasis. $\mathbf{J}$ Rheumatol 1990; 17: 487-90.

15. Torre Alonso BJC, Rodriguez Perez A, Arribas Castrillo JM, Ballina Garcia J, Riestra Noriega JL, Lopez Larrea C. Psoriatic arthritis (PA): a clinical, immunological and radiological study of 180 patients. Br J Rheumatol 1991; 30: 245-50.

16. Gladman DD, Farewell VT. The role of HLA antigens as indicators of disease progression in psoriatic arthritis. Arthritis Rheum 1995; 38: 845-50.

17. Salvarani C, Lo Scocco G, Macchioni P, Cremonesi T, Rossi F, Mantovani W, et al. Prevalence of psoriatic arthritis in Italian psoriatic patients. J Rheumatol 1995; 22: $1499-503$.

18. Tsai Y, Chang DM, Kuo SY, Wang WM, Chen YC, Lai JH. Relationship between human lymphocyte antigenB27 and clinical features of psoriatic arthritis. J Microbiol Immnol Infect 2003; 36: 101-4.

19. Queiro R, Sarasqueta C, Belzunegui J, Gonzalez C, Figueroa M, Torre Alonso JC. Psoriatic spondyloarthropathy: a comparative study between HLA-B27 positive and HLA-B27 negative disease. Semin Arthritis Rheum 2002; $31: 413-8$.

20. Elkayam O, Segal R, Caspi D. Human leukocyte antigen distribution in Israeli patients with psoriatic arthritis. Rheumatol Int. 2004; 24: 93-7.

21. Groh V, Steinle A, Bauer S, Spies T. Recognition of stress-induced MHC molecules by intestinal epithelial T cells. Science 1998; 279: 1737-40.
22. Fisher G, Arguello JR, Perez-Rodriguez M, McWinnie A, Marsh SG, Travers PJ et al. Sequence-specific oligonucleotide probing for MICB alleles reveals associations with MICA and HLA-B. Immunogenetics 2000; 51: 591-9.

23. Gonzalez S, Martinez-Borra J, Torre-Alonso JC, Gonzalez-Rochews S, Sanchez del Rio J, Rodriguez Perez A, Brautbar C et al. The MICA-A9 triplet repeat polymorphsm in the transmembrane region confers additional susceptibility to develop psoriatic arthritis, and is independent of the association of $\mathrm{Cw}^{*} 0602$ in psoriasis. Arthritis Rheum 1999; 42: 1010-6.

24. Gonzalez S, Brautbar C, Martinez-Borra J, LopezVazquez A, Segal R, Blanco-Gelaz MA et al. Polymorphism in MICA rather than HLA-B/C genes is associated with psoriatic arthritis in the Jewish population. Hum Immunol 2001; 62: 632-8.

25. Gonzalez S, Martinez-Borra J, Lopez-Vazquez A, Garcia-Fernandez S, Torre-Alonso JC, Lopez-Larrea C. MICA rather tha MICB, TNFA, or HLA-DRB1 is associated with susceptibility to psoriatic arthritis. J Rheumatol 2002; 29: 973-8.

26. Mossner R, Kingo K, Kleensang A, Kruger U, Konig IR, Silm $\mathrm{H}$ et al. Association of TNF -238 and -308 promoter polymorphism $\mathrm{s}$ with psoriasis vulgaris and psoriatic arthritis but not with pustulosis palmoplantaris. $\mathrm{J}$ Invest Dermatol, 2005; 124: 282-4.

27. Holer T Grossman S, Stradman-Bellinghausen B, Kaluza W, Reuss E, de Vlam K, Veys E, Marker-Herrmann E. Differential association of polymorphisms in the TNF $\alpha$ region with psoriatic arthritis but not psoriasis. Ann Rheum Dis 2002; 61: 213-8.

28. Hamamoto Y, Tateno H, Ishida T, Muto M. Lack of association between promoter polymorphisms of the tumor necrosis factor-alpha gene and psoriatic arthritis in Japanese patients. J Invest Dermatol 2000; 115: 11624.

29. Al-Heresh AM, Proctor J, Janes SM, Dixey J, Cox B, Welsh $\mathrm{K}$ et al. Tumor necrosis factor-alpha polymorphism and the HLA-Cw*0602 allele in psoriatic arthritis. Rheumatology (Oxford) 2002; 41: 525-30.

30. Bolding J, Kane D, Livingstone W, Mynett-Johnson L, Bresnihan B, Smith O et al. Cytokine gene polymorphisms: association with psoriatic arthritis susceptibility and severity. Arthritis Rheum 2003; 48: 1408-13.

31. Rahman P, Siannis F, Butt C, Farewell V, Peddle L, Pellett $\mathrm{F}$ et al. TNF- $\alpha$ polymorphisms and risk of psoriatic arthritis. Ann Rheum Dis 2006; 65: 919-23. 